\title{
EXPRESSION OF ANTIOXIDANT ENZYMES GENES IN THE LIVER AND CARDIAC TISSUES OF RATS UNDER L-CARNITINE ADMINISTRATION AND HIGH-INTENSITY INTERVAL EXERCISE TRAINING
}

\author{
B. SHAHOUZEHI ${ }^{1,2}$, Y. MASOUMI-ARDAKANI ${ }^{3}$, S. AMINIZADEH ${ }^{3}, H_{\text {. NASRI }}^{2 \bowtie}$ \\ ${ }^{1}$ Student Research Committee, Kerman University of Medical Sciences, Kerman, Iran; \\ ${ }^{2}$ Cardiovascular Research Center, Institute of Basic and Clinical Physiology \\ Sciences, Kerman University of Medical Sciences, Kerman, Iran; \\ ${ }^{3}$ Physiology Research Center, Institute of Neuropharmacology, \\ Kerman University of Medical Sciences, Kerman, Iran; \\ 凶e-mail:dr_hrnasri@yahoo.com
}

Received: 29 September 2020; Accepted: 07 July 2021

Reactive oxygen and nitrogen species are produced in the body both in normal and pathological processes and can alter cell redox and affect cell functions. Exercise training is able to modulate oxidant/ antioxidants balance. In this study, we aimed to evaluate expression of antioxidant enzymes genes in the liver and cardiac tissues of rats that performed high-intensity interval training (HIIT) and received L-carnitine (LCAR). Thirty-two male Wistar rats were were randomly assigned into 4 groups $(n=8)$ as follows: 1 . Untreated control; 2. The group that received LCAR (200 mg/kg/day i.p.); 3. The group that performed HIIT on a readmill (5 days/week for 4 weeks); 4. The group that received LCAR and performed HIIT. At the end of the study, liver and cardiac tissues were excised and used to quantify glutathione peroxidase (GPX), superoxide dismutase (SOD), catalase (CAT) and NF- $\kappa B$ genes expression by real-time PCR. It was found that both in LCAR and HIIT groups GPX, SOD and NF- $\kappa B(P<0.01)$ expression in cardiac and liver tissues was significantly increased compared to the indices in the control group. In LCAR-HIIT group SOD and NF- $\kappa B$ expression in the liver was significantly increased compared to the group that received LCAR only $(P=0.046)$. Our results showed that LCAR supplementation is useful to improve oxidative status in cardiac and liver tissues of rat during exercise training.

Ke y wo rds: L-carnitine, $N F-\kappa B, G P X, S O D$, high-intensity interval training.

$\mathrm{R}$ eactive oxygen and nitrogen species (RONS) are continuously produced in the body due to the normal physiological processes of the cell [1]. These compounds are able to damage macromolecules, alter cell redox, and ultimately affect cell function $[2,3]$. RONS oxidative effects are neutralized and limited by antioxidants, including enzymes such as catalase (CAT), superoxide dismutase (SOD) and glutathione peroxidase (GPX), and nonenzymatic antioxidant compounds (Vitamins $\mathrm{C}$ and E). An imbalance between RONS production and the function of the antioxidant system can lead to impaired control and signaling of cellular redox or mo- lecular damage called oxidative stress $[4,5]$. NF- $\mathrm{kB}$ transcription factor, which is a rapid-acting protein, is activated by substances such as reactive oxygen species (ROS) and is involved in the production of cytokines and cell survival [3].

$\mathrm{NF}-\kappa \mathrm{B}$ is a transcription factor involved in regulation of inflammation, immunity and apoptosis, and cell growth and differentiation. There are several sources of ROS in cells, which are divided into two main categories, the first of which includes the biological processes by which ROS is produced as a by-product, and the second one is including the processes that intentionally increase ROS production.

(C) 2021 Shahouzehi B. et al. This is an open-access article distributed under the terms of the Creative Commons Attribution License, which permits unrestricted use, distribution, and reproduction in any medium, provided the original author and source are credited. 
Mitochondria are placed in the first category. During electron transport chain (ETC) in mitochondria there is the chance of ROS production. The enzymes such as SOD and CAT and also antioxidant systems including Thioredoxin and Glutathione showed important role to neutralize the produced ROS [6]. One of the most important ways by which $\mathrm{NF}-\kappa \mathrm{B}$ reduces ROS levels is promotion of antioxidant defense. SOD is perhaps the most well-known target of NF- $\kappa B$ with antioxidant activity that saves cells from oxidative stress, by converting superoxide anion $\left(\mathrm{O}_{2}{ }^{-}\right)$ to hydrogen peroxide $\left(\mathrm{H}_{2} \mathrm{O}_{2}\right)$. GPX is a cytoplasmic enzyme that converts $\mathrm{H}_{2} \mathrm{O}_{2}$ to water and uses glutathione as a substrate [6].

High-intensity interval training (HIIT) has recently become popular, because it is effective at a specific time compared to traditional methods that are time consuming (such as endurance training). HIIT has been shown to increase mitochondrial enzyme activity and increase muscle oxidative capacity compared to conventional endurance training methods $[7,8]$. The change in redox homeostasis is induced by physiological and non-physiological stimuli such as acute aerobic and anaerobic exercise [9]. Ashton et al. showed that maximal exercise tripled the concentration of serum free radicals and also increased the amount of malondialdehyde (MDA), which is an indicator of lipid peroxidation [10]. There are other studies that have shown that acute exercise with varying intensity and duration led to a change in redox homeostasis [11-14]. In another study of athletes, it was found that exercise training reduced MDA and CAT, and on the other hand, the activity of SOD and GPX in these individuals did not show any significant change compared to the control group [15]. Emami et al. reported that HIIT increased GPX activity and decreased MDA in the liver tissue of diabetic rats [16]. HIIT has also been shown that led to electron leakage into mitochondria that result in detrimental effects on cells function and viability [17].

The $\beta$-hydroxy- $\gamma$-trimethylammonium butyrate (L-carnitine; LCAR) is known as an aminoacid and vitamin-like substance, and the L-isoform of carnitine has physiological activity $[18,19]$. The main role of LCAR in the body is to facilitate the oxidation of lipids by transporting long-chain fatty acids (LCFA) into the mitochondrial matrix (the site of $\beta$-oxidation). Therefore, without LCAR, most dietary lipids cannot be used as an energy source, and fatty acids accumulate in the body, eventually leading to obesity $[18,19]$. A study by Terruzzi et al. showed that LCAR reduces oxidative stress in human osteoblast-like cells and has beneficial antioxidant effects [20]. Vacante et al. found that LCAR increased the survival of cardiac cells under oxidative stress [21]. The administration of $300 \mathrm{mg} / \mathrm{kg} / \mathrm{d}$ of LAR resulted in decreased MDA and increased the activity of SOD, CAT and GPX [22]. Parandak et al. reported that daily consumption of $2 \mathrm{~g}$ of LCAR supplement for 2 weeks during endurance exercise reduces the effects of lipid peroxidation and muscle damage [23]. In contrast, Lee et al. reported no effect of LCAR supplementation on lipid $\beta$-oxidation and consumption of free fatty acids during 6 weeks of endurance training [24].

There are not many studies on the expression of antioxidant genes during HIIT. Nowadays, LAR is available as a supplement, and one of its most important effects is weight loss and improving physical condition. On the other hand, our society is facing another important problem called inactivity with sedentary life style that often leads to chronic diseases that increased trend of oxidative stress which are accompanied by metabolic diseases associated with oxidative stress. Despite researches on the effect of exercise and LAR on antioxidant defense but studies that evaluated the expression of antioxidants gene expression are limited and most studies evaluated antioxidants activity. Therefore, we presented this study to evaluate the effects of LCAR, HIIT and combination of both on the expression of NF- $\mathrm{kB}$ and some antioxidant genes (GPX, SOD, and CAT) in the liver and cardiac tissues of male Wistar rats.

\section{Materials and Methods}

Materials. L-carnitine (Sigma, L-carnitine hydrochloride, Cat number: C0283), Total RNA extraction kit (BioBasic, EZ-10 Spin Column Total RNA Miniprep Kit, Cat number: BS82312), cDNA synthesis kit (TAKARA, Prime Script RT Reagent Kit, Cat number: RR037A), 2X SYBR Green (Ampliqon, Cat number: A325402), and primers (purchased from Metabion, Germany).

Methods. All animals care and procedures were conducted in accordance with the European Convention for the protection of animals used for experimental and other scientific purposes (Strasbourg, 1986). This study was approved by the ethics committee of Kerman University of Medical Sciences with number, IR.KMU.REC.1398.356. 
Animals. Thirty-two male Wistar rats (175 \pm 10 g) were purchased from Physiology Research Center and were maintained at a controlled condition as follows; 12/12 h cycles of light/dark and $23 \pm 2^{\circ} \mathrm{C}$. After 10 days acclimatization the animals were randomly assigned into 4 groups $(n=8)$ as follow; Group 1 control which did not receive carnitine, Group 2 received $200 \mathrm{mg} / \mathrm{kg} /$ day LCAR by i.p. injections, Group 3 HIIT training group, and Group 4 that received $200 \mathrm{mg} / \mathrm{kg} /$ day LCAR and performed HIIT training $[25,26]$.

HIIT training protocol. The groups to be trained (groups 3 and 4) were familiarized with treadmill running that were performed at a speed of 10-25 meters/min. The HIIT program was done in 10 repetition of 1 min followed by 2 min of active rest. The rats started their training protocol at a speed of 20 meters/minute and finally the training finished at a speed of 45 meters/min. In addition to the time spent on the main workout, 5 min for warm-up and 5 min for cooling was also included in the protocol. HIIT training was last 4 weeks (5 days a week) [27]. Forty-eight hours after the end of the last training session, the animals were anesthetized and their liver and cardiac tissues were extracted and stored at $-80^{\circ} \mathrm{C}$ for real-time-PCR measurements [20].

Total RNA extraction and cDNA synthesis. The liver and cardiac tissues for each sample were used for RNA extraction. We dissected about $50 \mathrm{mg}$ of liver and cardiac tissues and homogenized at a specific lysis buffer by using Heilscher Sonicator (Heilscher H200, Germany). The homogenate for each sample was loaded in to the EZ-10 spin column and the total RNA was extracted according to the kit procedure. We checked the extracted RNA quality by Nano-drop instrument and after the quality was confirmed we used the extracted RNA for next step. Then after, we used 500 ng of total RNA to cDNA synthesis that was performed by TAKARA cDNA synthesis kit according to the kit's protocol [23].
Real-time PCR. The real-time PCR reactions were performed by ABI Step one plus instrument. Each Real-time PCR reaction was contained $10 \mu \mathrm{l}$ SYBR green, synthesized cDNA (100 ng), forward $\&$ reverse primers $(1 \mu \mathrm{l}$ from each primer), and the reaction volume reached to $20 \mu \mathrm{l}$ by distilled water. The annealing temperature was determined according to each primers Tm and by gradient PCR performed in Bio-Rad thermocycler. The thermal protocol in real-time PCR was as follow; 95 (10 min), 95 (20 sec), annealing temperature (50 sec), 40 cycles and after the thermal cycles were finished the melt curve analysis was performed. We used 18S rRNA as housekeeping gene. The relative expression of genes was determined by $2^{-\Delta \Delta \mathrm{Ct}}$ method [23]. Specific primers were used to perform real-time PCR measurements (Table 1).

Statistical analysis. Data analysis was performed using SPSS software. One-way analysis of variance (ANOVA) used to determine the differences in variables between groups along with Tukey's posthoc test. In all statistical comparisons, a significance level of $P<0.05$ was considered as significant.

\section{Results}

Gene expression in liver tissue. Gene expression analysis by real-time PCR showed that LCAR administration significantly increased GPX $(P=0.012)$, SOD $(P=0.003)$, and NF- $\kappa \mathrm{B}(P<0.001)$ expression compared to the control group in the liver (Fig. 1, 2, and 4). HIIT significantly increased SOD

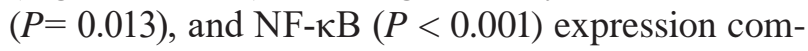
pared to the control group in the liver (Fig. 2 and 4). The difference in CAT expression was not significant between studied groups (Fig. 3).

Gene expression in cardiac tissue. Gene expression analysis by real-time PCR showed that LCAR administration significantly increased GPX $(P=0.001)$, SOD $(P=0.002)$, and NF- $\kappa \mathrm{B}(P<0.001)$ expression compared to the control group in the

Ta ble 1. The primers sequences that used in this study in order to perform real-time PCR

\begin{tabular}{cll}
\hline Genes name & \multicolumn{1}{|c}{ Forward primer } & \multicolumn{1}{c}{ Reverse primer } \\
\hline CAT & TAAGACTGACCAGGGCATC & CAAACCTTGGTGAGATCGAA \\
GPX & GGTGTTCCAGTGCGCAGAT & GGGCTTCTATATCGGGTTCGA \\
NFkB & AACACTGCCGAGCTCAAGAT & CATCGGCTTGAGAAAAGGAG \\
SOD & CCACTGCAGGACCTCATTTTAAT & TCTCCAACATGCCTCTCTTCATC \\
$18 \mathrm{~s}$ & CTTAGAGGGACAAGTGGCG & ACGCTGAGCCAGTCAGTGTA \\
\hline
\end{tabular}




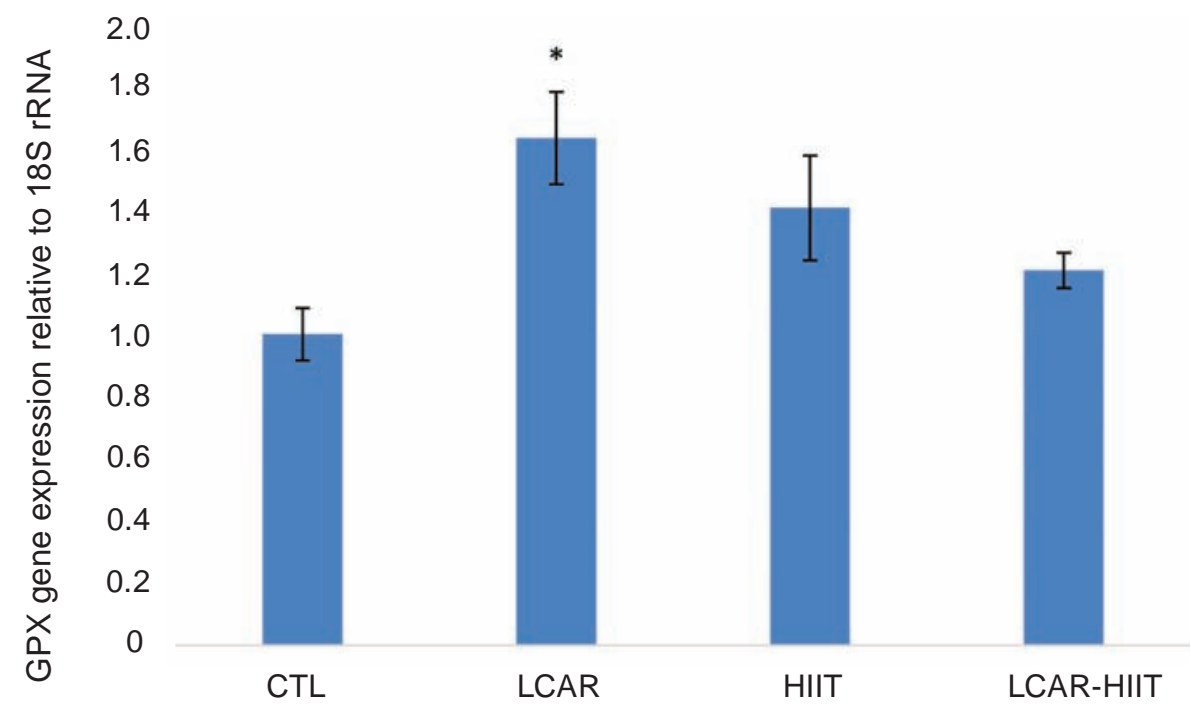

Fig. 1. GPX gene expression measured by real-time PCR in studied groups. CTL (untreated sedentary control), LCAR (received $200 \mathrm{mg} / \mathrm{kg} / \mathrm{d}$ of LCAR by i.p. injections), HIIT (performed exercise training), and LCARHIIT. Data are expressed as mean \pm SEM, $(n=8)$. *Statistically significant compared to CTL group

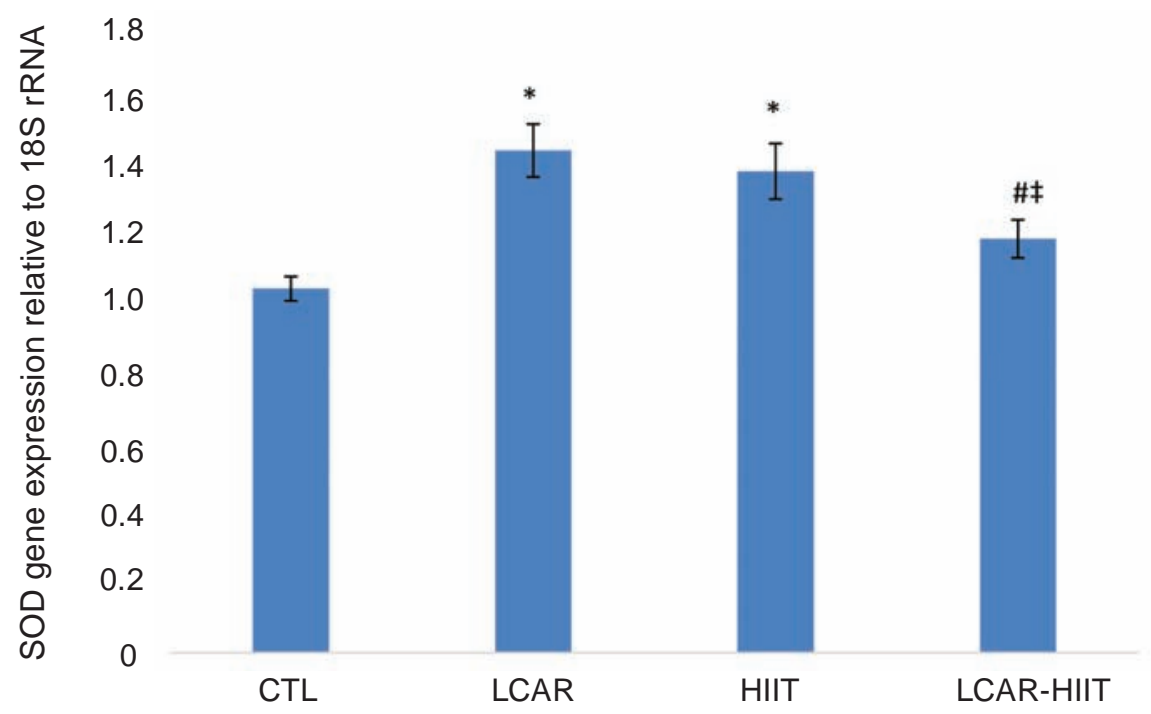

Fig. 2. SOD gene expression measured by real-time PCR in studied groups. CTL (untreated sedentary control), LCAR (received $200 \mathrm{mg} / \mathrm{kg} / \mathrm{d}$ of LCAR by i.p. injections), HIIT (performed exercise training), and LCARHIIT. Data are expressed as mean \pm SEM, $(n=8)$. *Statistically significant compared to CTL group. ${ }^{*}$ Statistically significant compared to LCAR group. ${ }^{\ddagger}$ Statistically significant compared to HIIT group

cardiac tissue (Fig. 5, 6, and 8). HIIT significantly increased GPX $(P=0.03)$, SOD $(P=0.009)$, and NF$\kappa \mathrm{B}(P=0.011)$ expression compared to the control group (Fig. 5, 6, and 8). The combination of LCARHIIT significantly increased GPX ( $P=0.003)$, SOD $(P=0.019)$, and NF-кB $(P=0.021)$ expression compared to the control group (Fig. 5, 6, and 8). CAT expression was not significant between studied groups (Fig. 7).

\section{Discussion}

The change in redox homeostasis is induced by physiological and non-physiological stimuli such as acute aerobic and anaerobic exercise training [9]. ROS production is accepted by mitochondria, and the ETC is one of the major sites for the production of free radicals. It has also been shown that increased $\beta$-oxidation of fatty acids promote ROS production [28]. When ROS levels exceed antioxidant capacity, 


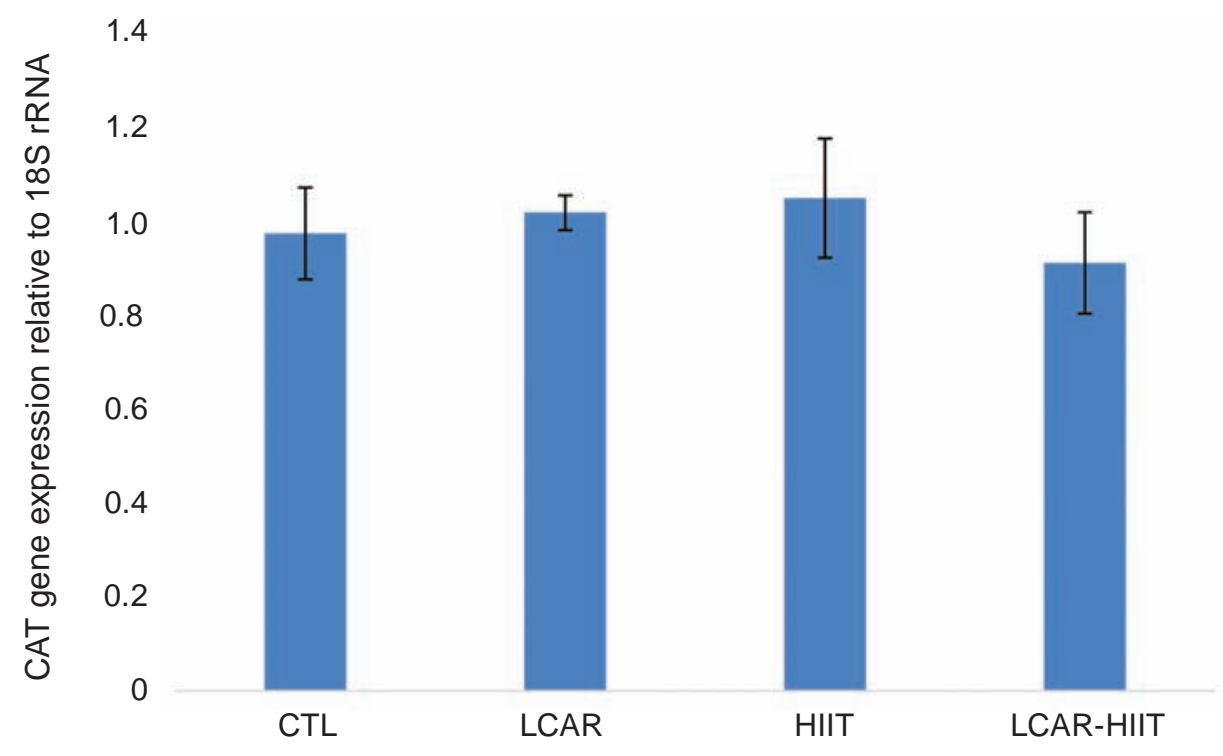

Fig. 3. CAT gene expression measured by real-time PCR in studied groups. CTL (untreated sedentary control), LCAR (received $200 \mathrm{mg} / \mathrm{kg} / \mathrm{d}$ of LCAR by i.p. injections), HIIT (performed exercise training), and LCARHIIT. Data are expressed as mean \pm SEM, $(n=8)$

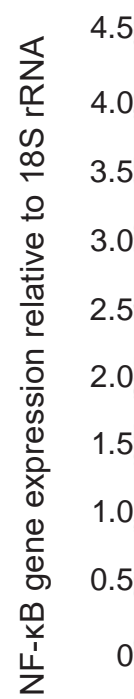

0
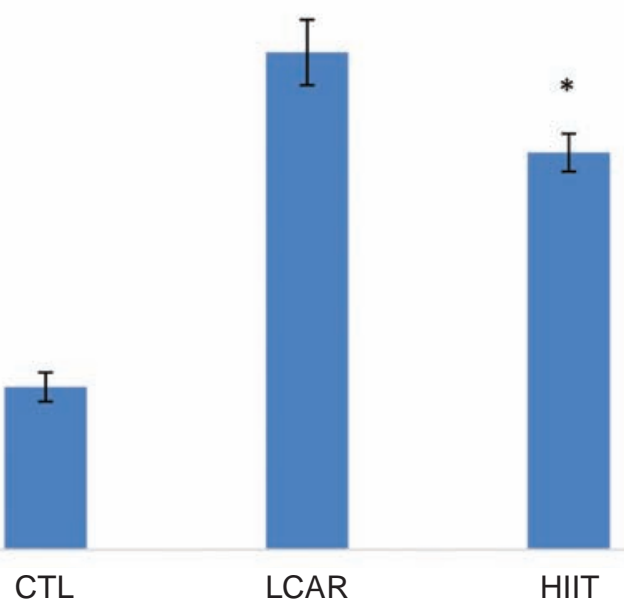

Fig. 4. NF- $\kappa B$ gene expression measured by real-time PCR in studied groups. CTL (untreated sedentary control), LCAR (received $200 \mathrm{mg} / \mathrm{kg} / \mathrm{d}$ of LCAR by i.p. injections), HIIT (performed exercise training), and LCAR-HIIT. Data are expressed as mean $\pm S E M,(n=8)$. *Statistically significant compared to CTL group. ${ }^{\#}$ Statistically significant compared to LCAR group. ${ }^{*}$ Statistically significant compared to HIIT group

it leads to a condition called oxidative stress, which is associated with the pathogenesis of many diseases. ROS molecules cause cell damage by reacting with proteins (cysteine roots), lipids (lipid peroxidation), and nucleic acids (DNA damage and breakdown) [29]. Therefore, reducing ROS production and elevation of antioxidant defense system is very important. In current study, we examined LCAR supplemen- tation and HIIT effects on the expression of GPX, SOD, CAT and NF- $\kappa$ B in the liver and cardiac tissue of rats. Our data showed that L-carnitine supplementation and HIIT training improved oxidative defense in rats.

During exercise, changes in blood flow occur and cells that are more active and involved in the process receive more blood flow. However, it is 


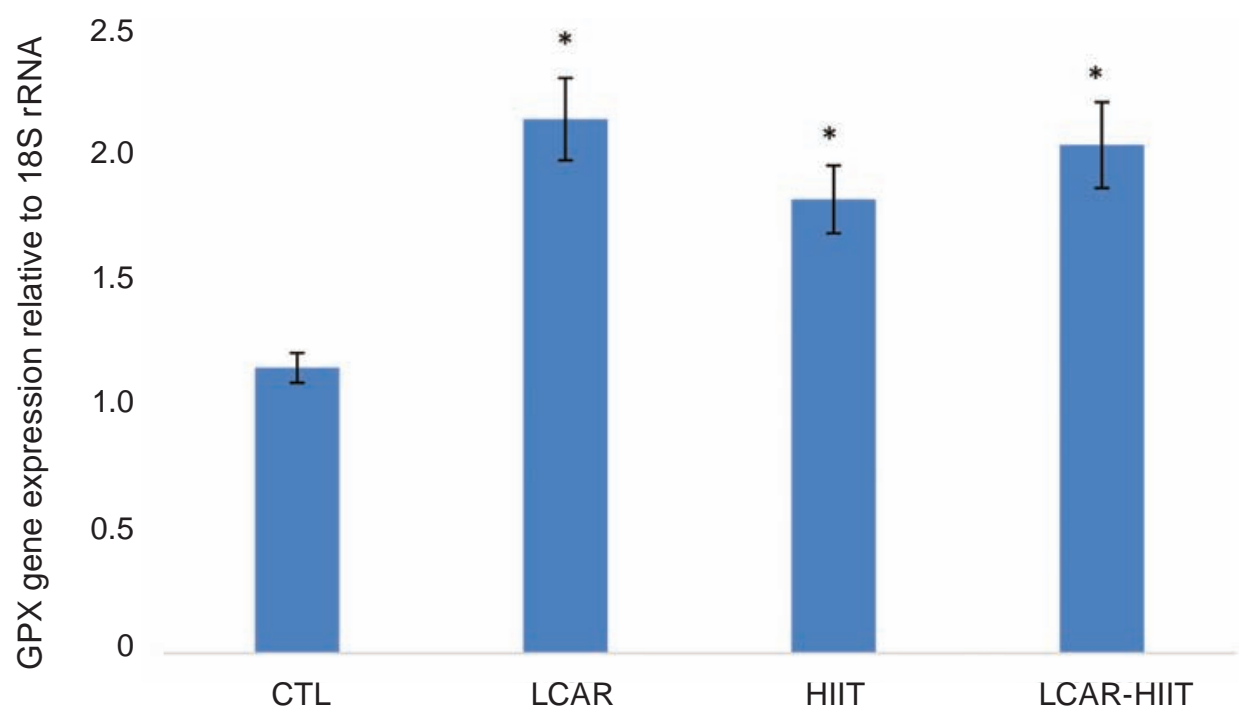

Fig 5. GPX gene expression measured by real-time PCR in studied groups. CTL (untreated sedentary control), LCAR (received $200 \mathrm{mg} / \mathrm{kg} / \mathrm{d}$ of LCAR by i.p. injections), HIIT (performed exercise training), and LCAR-HIIT. Data are expressed as mean $\pm S E M,(n=8)$. *Statistically significant compared to CTL group

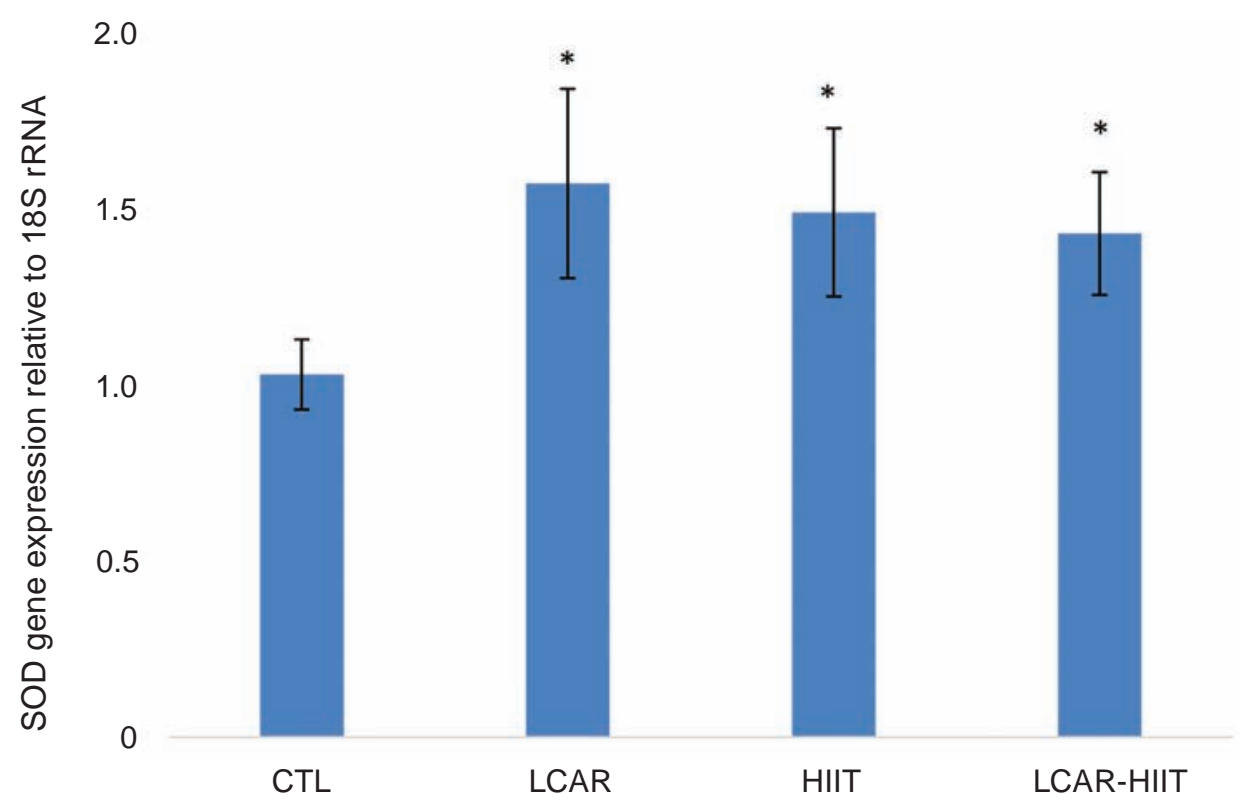

Fig 6. SOD gene expression measured by real-time PCR in studied groups. CTL (untreated sedentary control), LCAR (received $200 \mathrm{mg} / \mathrm{kg} / \mathrm{d}$ of LCAR by i.p. injections), HIIT (performed exercise training), and LCAR-HIIT. Data are expressed as mean $\pm S E M,(n=8)$. *Statistically significant compared to CTL group

still possible for these tissues, especially muscles, to experience hypoxia. Finally, the production of free radicals from the mitochondrial source may occur in the absence of oxygen [30]. Acute exercise with varying intensity and duration led to a change in redox homeostasis [11-14]. It was reported that performing HIIT improves aerobic and anaerobic function [31]. HIIT has also been shown to lead to electron leakage into mitochondria, which can have detrimental effects on cells [17].

Ten weeks of HIIT increased the activity of SOD and GPX enzymes in obese rat muscle [32]. Emami et al. reported that HIIT increased GPX activity and decreased MDA in the liver tissue of diabetic rats [16]. HIIT was more effective than MICT in improving antioxidative defense in diabetes and 


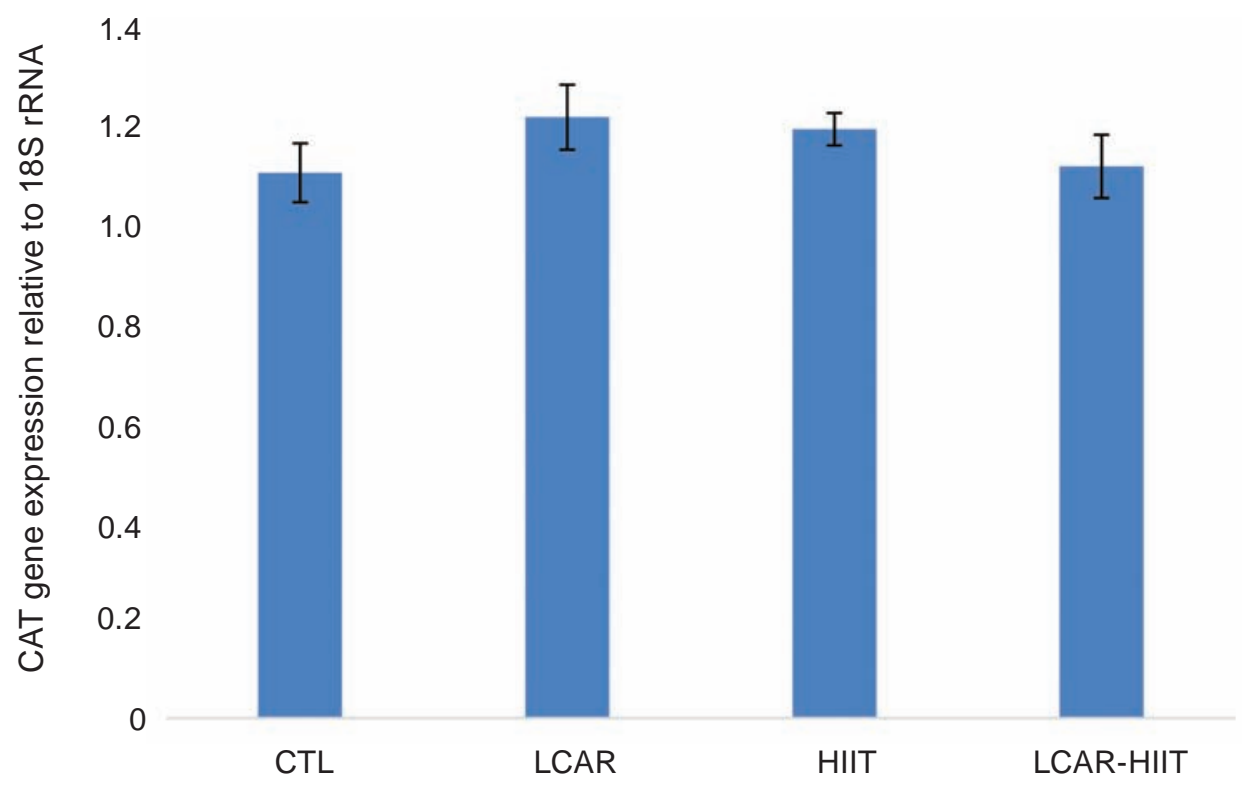

Fig. 7. CAT gene expression measured by real-time PCR in studied groups. CTL (untreated sedentary control), LCAR (received $200 \mathrm{mg} / \mathrm{kg} / \mathrm{d}$ of LCAR by i.p. injections), HIIT (performed exercise training), and LCAR-HIIT. Data are expressed as mean $\pm S E M,(n=8)$

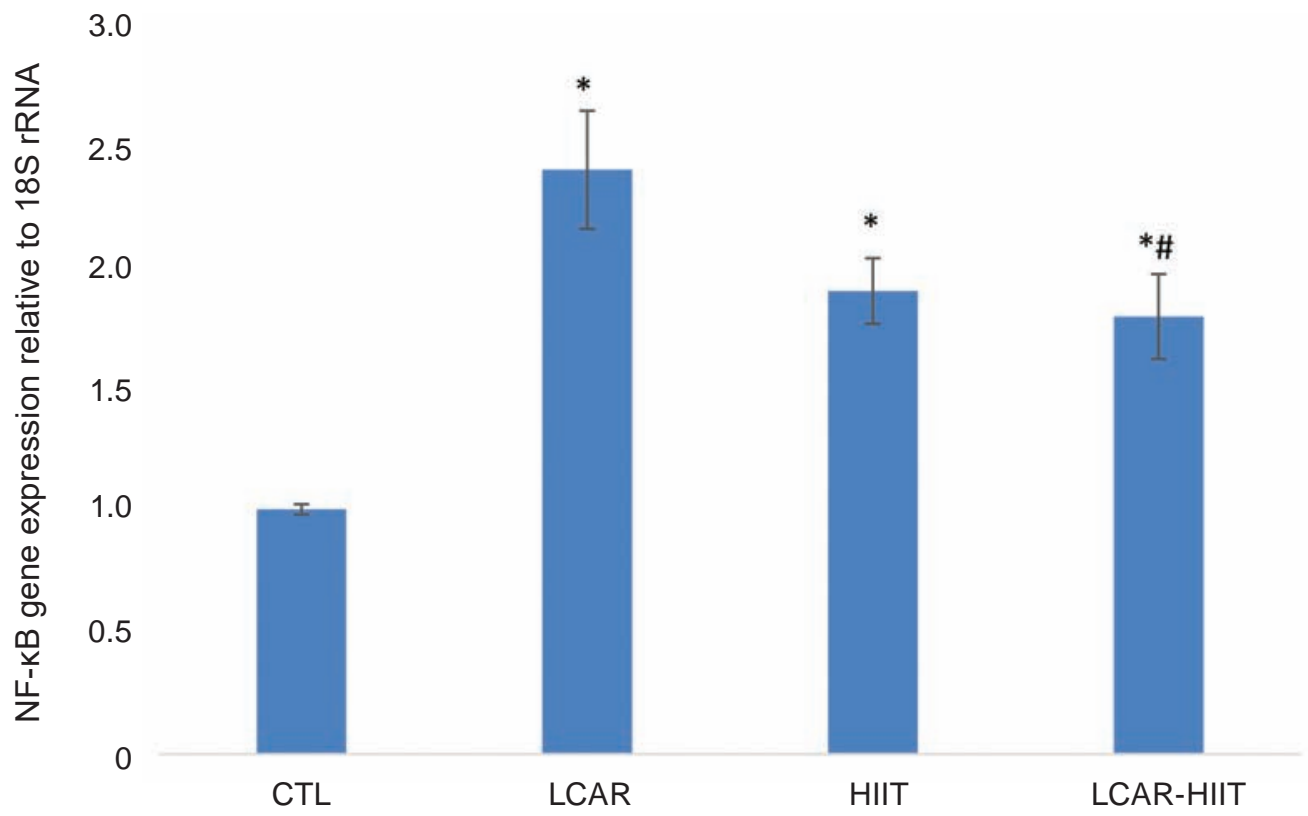

Fig. 8. NF- $\kappa B$ gene expression measured by real-time PCR in studied groups. CTL (untreated sedentary control), LCAR (received $200 \mathrm{mg} / \mathrm{kg} / \mathrm{d}$ of LCAR by i.p. injections), HIIT (performed exercise training), and LCAR-HIIT. Data are expressed as mean \pm SEM, $(n=8)$. *Statistically significant compared to CTL group. \#Statistically significant compared to LCAR group

increased GPX levels, but SOD levels were not significant [33]. Our data over SOD and GPX gene expression are the same as these studies. But there are other studies that are in contrast to our study. CAT activity was reduced in athletes but SOD and GPX activity did not show a significant change compared to the control group [15]. Performing 8 weeks of HIIT in rats with chronic kidney disease (CKD) resulted in a significant increase in SOD and CAT expression but no significant increase in GPX expres- 
sion [34]. Six week HIIT significantly increased CAT expression but no significant increase in SOD [35]. In some studies, CAT activity was increased after exercise training [34-36], but in the present study, its expression did not change in cardiac and liver tissue. In sum, as is clear from above mentioned studies that HIIT has beneficial effects on antioxidant enzyme activity and expression. However, regarding the existing contradictions and inconsistencies, it can be noted that the target tissue, study duration and exercise training protocol were different between studies. But what most of these studies had in common with the present study was the beneficial effect of HIIT on the antioxidant defense system.

The study by Ishikawa et al. showed that LCAR administration increased the expression of SOD, GPX and CAT genes expression in the liver [36]. In our study, LCAR also increased the expression of SOD and GPX, which is consistent with the study of Ishikawa et al., but in contrast, the LCAR supplementation in current study on CAT gene expression had no effect. A study by Terruzzi et al. (2019) showed that LCAR reduced oxidative stress in human osteoblast-like cells and has beneficial antioxidant effects [20]. Another study in rats on a highfructose diet showed that LCAR supplementation improved oxidative stress and inflammation, so that administration of $300 \mathrm{mg} / \mathrm{kg} / \mathrm{d}$ of LCAR resulted in decreased MDA and increased the activity of SOD, CAT and GPX [22]. These studies generally confirmed antioxidant effects of LCAR, although most of these studies have examined the activity of antioxidant enzymes, while in our study we examined the positive effects of LCAR on the expression of antioxidant enzyme genes (SOD and GPX) in both cardiac and liver tissues.

Nurani Pilehrud et al. in their study of the effect of LCAR administration (3 g/d for 2 weeks) in basketball players, found that LCAR reduced harmful oxidative changes during exercise training by increasing the activity of SOD, CAT, GPX and glutathione reductase [37]. Parandak et al. (2014) reported that daily consumption of $2 \mathrm{~g}$ of LCAR supplement for 2 weeks during endurance exercise reduces the effects of lipid peroxidation and muscle damage [23]. These two studies are in line with the results of our study and showed that LCAR supplementation and HIIT improve the antioxidative status. However, our results did not show an additive or synergistic effect of the combination of LCAR-HIIT on gene expression, which may be due to adaptation during 4 weeks of treatment or upstream pathway adjustments. In contrast, Lee et al. (2017) reported no effect of LCAR supplementation on fat beta-oxidation and consumption of free fatty acids during 6 weeks of endurance training [24].

The role of ROS in NF- $\kappa$ B activation has been previously identified. NF- $\kappa \mathrm{B}$ plays an important protective role against oxidative stress by suppressing ROS accumulation. Inhibition of NF- $\mathrm{KB}$ activation has also been shown to increase ROS production by TNF- $\alpha$, protein oxidation, and lipid peroxidation. Activation of NF- $\kappa B$ is also essential for cell recovery under oxidative stress conditions. NF- $\kappa \mathrm{B}$-induced antioxidant targets include glutathione-S-transferase (GST), glutathione peroxidase, metallothionein-3, heme oxygenase-1, and NADPH dehydrogenase [29]. ROS accumulation has been reported in cells without NF- $\kappa \mathrm{B}$, which is due to decreased expression of NF- $\kappa \mathrm{B}$ antioxidant targets such as SOD [38].

Oxidative stress induced by exercise training affects the NF- $\kappa B$ signaling pathways, activating the antioxidant response including SOD, GPS, NOS, and catalase [33]. Ashton et al. showed that maximal exercise tripled the concentration of serum free radicals and also increased the amount of malondialdehyde (MDA), which is an indicator of lipid peroxidation [10]. Exercise training on a treadmill for 8 weeks increased the expression of NF- $\kappa B$ protein in heart tissue in aged mice [39]. Endurance training had no effect on NF- $\mathrm{KB}$ expression in cardiac tissue [40]. 8 weeks of moderate exercise reduced NF- $\kappa B$ expression in the skeletal muscle of diabetic rats [41]. The study by Ji et al. showed that the NF- $\mathrm{KB}$ signaling pathway is activated depending on the redox state during muscle contraction, possibly due to increased production of oxidants [42]. In response to increased ROS during exercise, especially when not exhaustive, NF- $\kappa \mathrm{B}$ activates the endogenous antioxidant system, and regulates enzymes such as GPX, glutathione reductase (GR), and CAT. The results of our study showed that LCAR and HIIT lead to a significant increase in NF- $\kappa \mathrm{B}$ gene expression in cardiac and liver tissues. It seems that oxidative stress induced during HIIT as well as increased ETC in mitochondria at the time of LCAR administration leads to increased cellular oxidative stress and in response of ROS production, NF- $\kappa \mathrm{B}$ expression increased which in turn leads to up-regulation of SOD and GPX expression. There are few evidence over the regulatory effect of NF- $\mathrm{KB}$ on catalase. Also, it was described that canonical NF- $\kappa$ B activa- 
tion down-regulates catalase [6]. Our data showed that although NF- $\mathrm{\kappa B}$ expression was increased, this increase had no effect on CAT expression, and it appears that if NF- $\kappa \mathrm{B}$ had an effect on CAT, it would take longer to observe its effect.

Conclusion. According to finding from current study the LCAR supplementation and performing HIIT probably increase mitochondrial metabolism and result in NF- $\kappa \mathrm{B}$ up-regulation that improve redox state, cell survival, and immunity. Therefore, either LCAR supplementation or performing HIIT can cause beneficial adaptations in cardiac and liver tissues.

Conflict of interest. Authors have completed the Unified Conflicts of Interest form at http://ukrbiochemjournal.org/wp-content/uploads/2018/12/ coi_disclosure.pdf and declare no conflict of interest.

Funding. This study was funded by Kerman Medical University Research Council.

Acknowledgements. The present article was financially supported by the Kerman Medical University Research Council.

\section{ЕКСПРЕСІЯ ГЕНІВ АНТИОКСИДАНТНИХ ЕНЗИМІВ У ТКАНИНАХ ПЕЧІНКИ ТА СЕРЦЯ ЩУРІВ ЗА ВВЕДЕННЯ L-КАРНІТИНУ ТА ВИСОКОІНТЕНСИВНОГО ІНТЕРВАЛЬНОГО ТРЕНУВАННЯ}

\section{B. Shahouzehi ${ }^{1,2}$, Y. Masoumi-Ardakani ${ }^{3}$, S. Aminizadeh ${ }^{3}, H$. Nasri ${ }^{2 凶}$}

\footnotetext{
${ }^{1}$ Student Research Committee, Kerman University of Medical Sciences, Kerman, Iran;

${ }^{2}$ Cardiovascular Research Center, Institute of

Basic and Clinical Physiology Sciences, Kerman

University of Medical Sciences, Kerman, Iran; ${ }^{3}$ Physiology Research Center, Institute of Neuropharmacology, Kerman University of Medical Sciences, Kerman, Iran; 凶e-mail: dr_hrnasri@yahoo.com
}

Реактивні форми кисню та азоту, що виробляються в організмі як за нормальних, так $\mathrm{i}$ за патологічних процесів, можуть порушувати окисно-відновний статус та впливати на функціонування клітин. Фізичне тренування здатне модулювати окисно-відновний баланс. Метою дослідження було оцінити експресію генів антиоксидантних ензимів у печінці та серцевій тканині щурів, які зазнавали високоінтенсивних інтервальних тренувань (НIIT) та отримували L-карнітин (LCAR). Самців лінії Wistar (32-щура) випадковим чином розподілили на 4 групи $(n=8): 1$ - контрольна група; 2 - група тварин, які отримували LCAR (200 мг/кг на добу, внутрішньочеревно); 3 - група тварин, які зазнавали HIIT на біговій доріжці (5 днів на тиждень протягом 4 тижнів); 4 - група тварин, які отримувала LCAR та зазнавали HIIT. У кінці дослідження печінку та серцеву тканину видаляли та використовували для кількісної оцінки експресії генів глутатіонпероксидази (GPX), супероксиддисмутази (SOD), каталази (CAT) та NF-кB методом ПЛР у реальному часі. Виявлено, що як LCAR, так і HIIT істотно посилювали експресію генів GPX, SOD та NF-кB $(P<0,01)$ у тканинах серця та печінки порівняно з показниками в контрольній групі. Експресія SOD та NF-кB у печінці була значно збільшеною у LCAR-HIIT групі тварин порівняно з групою, що отримувала лише LCAR $(P=0,046)$. Показано, що добавки LCAR $€$ корисними для поліпшення оксидативного балансу в серцевій та печінковій тканинах щурів під час тренувань.

К л юч о в і с лов а: L-карнітин, NF-кB, GPX, SOD, високоінтенсивні інтервальні тренування.

\section{References}

1. Dröge W. Free radicals in the physiological control of cell function. Physiol Rev. 2002; 82(1): 47-95.

2. Burdon RH, Rice-Evans C. Free radicals and the regulation of mammalian cell proliferation. Free Radic Res Commun. 1989; 6(6): 345-358.

3. Gloire G, Legrand-Poels S, Piette J. NF-kappaB activation by reactive oxygen species: fifteen years later. Biochem Pharmacol. 2006; 72(11): 1493-1505.

4. Bisbal C, Lambert K, Avignon A. Antioxidants and glucose metabolism disorders. Curr Opin Clin Nutr Metab Care. 2010; 13(4): 439-446.

5. Jones DP. Redefining oxidative stress. Antioxid Redox Signal. 2006; 8(9-10): 1865-1879.

6. Morgan MJ, Liu ZG. Crosstalk of reactive oxygen species and NF-kB signaling. Cell Res. 2011; 21(1): 103-115.

7. Zwetsloot KA, John CS, Lawrence MM, Battista RA, Shanely RA. High-intensity 
interval training induces a modest systemic inflammatory response in active, young men. $J$ Inflamm Res. 2014; 7: 9-17.

8. Coyle EF. Very intense exercise-training is extremely potent and time efficient: a reminder. J Appl Physiol. 2005; 98(6): 1983-1984.

9. Costa KB, Magalhães SM, Aguiar PF, Ottone VO, Tossige-Gomes R, Magalhães FC, Amorim FT, Rocha-Vieira E. Modification of Blood Redox Homeostasis by High-Intensity Interval Training. Reactive Oxygen Species. 2018; 5(13): 56-67.

10. Ashton T, Rowlands CC, Jones E, Young IS, Jackson SK, Davies B, Peters JR. Electron spin resonance spectroscopic detection of oxygencentred radicals in human serum following exhaustive. Eur J Appl Physiol Occup Physiol. 1998; 77(6): 498-502.

11. Tossige-Gomes R, Costa KB, Ottone Vde O, Magalhães Fde C, Amorim FT, Rocha-Vieira E. Lymphocyte Redox Imbalance and Reduced Proliferation after a Single Session of High Intensity Interval Exercise. PLoS One. 2016; 11(4): e0153647.

12. Cleto LS, Oleto AF, Sousa LP, Barreto TO, Cruz JS, Penaforte CL, Magalhães JC, SousaFranco J, Pinto KMC, Campi-Azevedo AC, Rocha-Vieira E. Plasma cytokine response, lipid peroxidation and NF-kB activation in skeletal muscle following maximum progressive swimming. Braz J Med Biol Res. 2011; 44(6): 546-552.

13. Hudson MB, Hosick PA, McCaulley GO, Schrieber L, Wrieden J, McAnulty SR, Triplett NT, McBride JM, Quindry JC. The effect of resistance exercise on humoral markers of oxidative stress. Med Sci Sports Exerc. 2008; 40(3): 542-548.

14. Barreto TO, Cleto LS, Gioda CR, Silva RS, Campi-Azevedo AC, de Sousa-Franco J, de Magalhães JC, Penaforte CL, Pinto KMC, Cruz Jdos S, Rocha-Vieira E. Swim training does not protect mice from skeletal muscle oxidative damage following a maximum exercise test. Eur J Appl Physiol. 2012; 112(7): 2523-2530.

15. Ugras AF. Effect of high intensity interval training on elite athletes' antioxidant status. Sci Sport. 2013; 28(5): 253-259.

16. Emami AM, Homaei HM, Azarbayejani MA. Effects of High Intensity Interval Training and Curcumin Supplement on Glutathione
Peroxidase (GPX) Activity and Malondialdehyde (MDA) Concentration of the Liver in STZ Induced Diabetic Rats. Iranian J Diab Obes. 2016; 8(3): 129-134.

17. Ramos-Filho D, Chicaybam G, de-SouzaFerreira E, Martinez CG, Kurtenbach E, Casimiro-Lopes G, Galina A. High Intensity Interval Training (HIIT) Induces Specific Changes in Respiration and Electron Leakage in the Mitochondria of Different Rat Skeletal Muscles. PLoS One. 2015; 10(6): e0131766.

18. Cha YS. Effects of L-carnitine on obesity, diabetes, and as an ergogenic aid. Asia Pac J Clin Nutr. 2008; 17(Suppl 1): 306-308.

19. Eskandari HG, Cimen MY, Tamer L, Kanik A, Atik U. Short term effects of L-carnitine on serum lipids in STZ-induced diabetic rats. Diabetes Res Clin Pract. 2004; 66(2): 129-132.

20. Terruzzi I, Montesano A, Senesi P, Villa I, Ferraretto A, Bottani M, Vacante F, Spinello A, Bolamperti S, Luzi L, Rubinacci A. L-Carnitine Reduces Oxidative Stress and Promotes Cells Differentiation and Bone Matrix Proteins Expression in Human Osteoblast-Like Cells. Biomed Res Int. 2019; 2019: 5678548.

21. Vacante F, Senesi P, Montesano A, Frigerio A, Luzi L, Terruzzi I. L-Carnitine: An Antioxidant Remedy for the Survival of Cardiomyocytes under Hyperglycemic Condition. J Diabetes Res. 2018; 2018: 4028297.

22. Hussein SA, Abd El-Hamid OM, Hemdan HS. Protective Effect of L-carnitine on Metabolic Disorders, Oxidative Stress, Antioxidant Status and Inflammation in a Rat Model of Insulin Resistance. Int J Biol Chem. 2014; 8(1): 21-36.

23. Parandak K, Arazi H, Khoshkhahesh F, Nakhostin-Roohi B. The effect of two-week L-carnitine supplementation on exercise -induced oxidative stress and muscle damage. Asian J Sports Med. 2014; 5(2): 123-128.

24. Lee JK, Lee JS, Park H, Cha YS, Yoon CS, Kim CK. Effect of L-carnitine supplementation and aerobic training on FABPc content and betaHAD activity in human skeletal muscle. Eur $J$ Appl Physiol. 2007; 99(2): 193-199.

25. Masoumi-Ardakani Y, Aminizadeh S, Fallah H, Shahouzehi B. L-Carnitine different doses affect serum and pancreas tissue Antioxidative defense and histopathology in STZ-induced diabetic rats. Biologia. 2020; 75(9): 1415-1423.

26. Masoumi-Ardakani Y, Fallah H, Shahouzehi B. Carnitine effects on serum and pancreas 
inflammatory response in diabetic rats. $U k r$ Biochem J. 2019; 91(6): 59-66.

27. Sobhani V, Mirdar S, Arabzadeh E, Hamidian G, Mohammadi F. High-intensity interval traininginduced inflammation and airway narrowing of the lung parenchyma in male maturing rats. Comp Clin Pathol. 2018; 27(3): 577-582.

28. Quijano C, Trujillo M, Castro L, Trostchansky A. Interplay between oxidant species and energy metabolism. Redox Biol. 2016; 8: 28-42.

29. Lingappan K. NF-кB in Oxidative Stress. Curr Opin Toxicol. 2018; 7: 81-86.

30. Poblete Aro CE, Russell Guzmán JA, Soto Muñoz ME, Villegas González BE. Effects of high intensity interval training versus moderate intensity continuous training on the reduction of oxidative stress in type 2 diabetic adult patients: CAT. Medwave. 2015; 15(7): e6212.

31. Bermejo FJ, Olcina O, Martínez I, Timón R. Effects of a HIIT protocol including functional exercises on performance and body composition. Arch Med Deporte. 2018; 35(6): 386-391.

32. Groussard C, Maillard F, Vazeille E, Barnich N, Sirvent P, Otero YF, Combaret L, Madeuf E, Sourdrille A, Delcros G, Etienne M, Teixeira A, Sauvanet P, Pialoux V, Boisseau N. TissueSpecific Oxidative Stress Modulation by Exercise: A Comparison between MICT and HIIT in an Obese Rat Model. Oxid Med Cell Longev. 2019; 2019: 1965364.

33. Vargas-Mendoza N, Morales-González Á, Madrigal-Santillán EO, Madrigal-Bujaidar E, Álvarez-González I, García-Melo LF, AnguianoRobledo L, Fregoso-Aguilar T, MoralesGonzalez JA. Antioxidant and Adaptative Response Mediated by Nrf2 during Physical Exercise. Antioxidants (Basel). 2019; 8(6): 196.

34. Tucker PS, Briskey DR, Scanlan AT, Coombes JS, Dalbo VJ. High intensity interval training favourably affects antioxidant and inflammation mRNA expression in early-stage chronic kidney disease. Free Radic Biol Med. 2015; 89: 466472.
35. Henríquez-Olguín C, Renani LB, ArabCeschia L, Raun SH, Bhatia A, Li Z, Knudsen JR, Holmdahl R, Jensen TE. Adaptations to highintensity interval training in skeletal muscle require NADPH oxidase 2. Redox Biol. 2019; 24: 101188.

36. Ishikawa H, Takaki A, Tsuzaki R, Yasunaka T, Koike K, Shimomura Y, Seki H, Matsushita H, Miyake Y, Ikeda F, Shiraha H, Nouso K, Yamamoto K. L-carnitine prevents progression of non-alcoholic steatohepatitis in a mouse model with upregulation of mitochondrial pathway. PLoS One. 2014; 9(7): e100627.

37. Nurani Pilehrud M, Nameni F, Ebadi Ghahremani M. Serum anti-oxidation enzymes response to L-carnitine supplementation females basketball players. Int J Bio-Inorg Hybr Nanomater. 2016; 5(3): 213-221.

38. Luedde T, Schwabe RF. NF- $\kappa B$ in the liver-linking injury, fibrosis and hepatocellular carcinoma. Nat Rev Gastroenterol Hepatol. 2011; 8(2): 108-118.

39. Pourheydar B, Biabanghard A, Azari R, Khalaji N, Chodari L. Exercise improves aging-related decreased angiogenesis through modulating VEGF-A, TSP-1 and p-NF-Kb protein levels in myocardiocytes. J Cardiovasc Thorac Res. 2020; 12(2): 129-135.

40. Shahedi V, Soori R. The Effect of Endurance Training and Purslane Seed Consumption on NF-kB and CRP in the Heart Tissue of Rats Exposed to Oxidative Damage Induced by $\mathrm{H}_{2} \mathrm{O}_{2}$. J Arch Mil Med. 2019; 7(1-2): e90524.

41. Liu HW, Chang SJ. Moderate Exercise

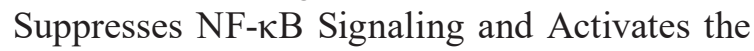
SIRT1-AMPK-PGC1 $\alpha$ Axis to Attenuate Muscle Loss in Diabetic db/db Mice. Front Physiol. 2018; 9: 636.

42. Ji LL, Gomez-Cabrera MC, Steinhafel N, Vina J. Acute exercise activates nuclear factor (NF)kappaB signaling pathway in rat skeletal muscle. FASEB J. 2004; 18(13): 1499-1506. 